\title{
Efektivitas Pelatihan dan Efikasi Diri dalam Meningkatkan Perilaku Berwirausaha pada Masyarakat Transisi
}

\author{
ASEP SAEPUDIN ${ }^{1}$, JAJAT S ARDIWINATA ${ }^{2}$, ILFIANDRA ${ }^{3}$, YAYA SUKARYA ${ }^{4}$ \\ 1,2 Departemen Pendidikan Luar Sekolah UPI, Jl. Dr. Setiabudhi 229 Bandung \\ ${ }^{3}$ Departemen Psikologi Pendidikan dan Bimbingan FIP UPI \\ ${ }^{4}$ UPTD SKB Kab. Bandung Jl. AA Wiranatakusumah 25 Bandung \\ email: aspudin@gmail.com¹, Jsardiplsupi@yahoo.co.id², Ifiandra_upi@yahoo.com³, yayasukarya1202075@gmail,com
}

\begin{abstract}
The success of a training activity is measured by how much change in the increase of knowledge, attitudes and skills of graduates, and the factors that influence these changes. Aim of this article to determine the effect of training effectiveness and entrepreneurial self-efficacy on behavior of participants after the training. The approach used is a quantitative approach with a descriptive method of research korelasional. Sampel is 30 respondents were taken by cluster sampling. Results this research is (1) Effect of training outcomes for the participants after the training in entrepreneurship behavior expressed by a simple linear regression equation that shows a positive price, the greater the degree of relationship between two variables is quite or moderate; (2) The effect of self-efficacy of the behavior of the participants after the training entrepreneurship is expressed by a simple linear regression equation that shows a positive price, the greater the degree of relationship between two variables is high or tight; (3) Effect of training and self efficacy results on the behavior of the participants after the training entrepreneurship is expressed by multiple linear regression equation that shows a positive price, with a large degree of correlation between these variables is high or tight.
\end{abstract}

Keywords: training, self efficacy, behavior, entrepreneurial

\begin{abstract}
Abstrak. Keberhasilan suatu kegiatan pelatihan diukur dari seberapa besar perubahan peningkatan pengetahuan, sikap dan keterampilan lulusannya, serta faktor yang memengaruhi perubahan tersebut. Artikel ini untuk mengetahui pengaruh efektivitas pelatihan dan efikasi diri terhadap perilaku berwirausaha peserta pascapelatihan. Pendekatan yang digunakan kuantitatif dengan metode deskriptif analisis korelasional. Sampel sebanyak 30 responden dengan teknik cluster sampling. Hasilnya adalah (1) Pengaruh hasil pelatihan terhadap perilaku berwirausaha peserta pascapelatihan dinyatakan dengan persamaan regresi linier sederhana yang menunjukkan harga positif, dengan besar derajat hubungan antara dua variabel tergolong cukup atau moderat; (2) Pengaruh efikasi diri terhadap perilaku berwirausaha peserta pasca pelatihan dinyatakan dengan persamaan regresi linier sederhana yang menunjukkan harga positif, dengan besar derajat hubungan antara dua variabel tergolong tinggi atau erat; (3) Pengaruh hasil pelatihan dan efikasi diri terhadap perilaku berwirausaha peserta pasca pelatihan dinyatakan dengan persamaan regresi linier ganda yang menunjukkan harga positif, dengan besar derajat hubungan antara variabel tersebut tergolong tinggi atau erat.
\end{abstract}

Kata Kunci: pelatihan, efikasi diri, perilaku, wirausaha.

\section{Pendahuluan}

Pendidikan nasional Indonesia merupakan sebuah pola terstruktur dan sistematis yang berakar pada kebudayaan bangsa Indonesia. Dalam Undang Undang Sistem Pendidikan Nasional No. 20 Tahun 2003, dijelaskan bahwa pendidikan di Indonesia diselengarakan dalam tiga jalur, yaitu pendidikan pada jalur formal, nonformal dan informal. Setiap jalur pendidikan dimaksud mewadahi berbagai jenjang dan jenis program pendidikan yang satu sama lain saling melengkapi. Pada jalur pendidikan non formal, program pendidikan diselenggarakan melalui bebagai satuan pendidikan, diantaranya adalah Pusat Kegiatan Belajar Masyarakat 
(PKBM). Oleh karena itu, dalam kerangka pendidikan nasional, PKBM memiliki peran strategis dalam menyelenggarakan program pendidikan dalam meningkakan kualitas masyarakat. Salah satu diantaranya adalah PKBM Jelita Masa yang berada di Kecamatan Majalaya, Kabupaten Bandung yang telah menyelenggarakan kegiatan pelatihan kewirausahaan dengan sasaran masyarakat yang membutuhkan dan lemah dari segi taraf hidupnya, dengan tujuan memberikan bekal pengetahuan dan keterampilan bagi peserta pelatihan yang tergabung dalam kelompok belajar, sehingga pada akhirnya peserta pelatihan dapat meningkatkan pendapatan dan taraf hidupnya secara pribadi dan kelompok. Masyarakat sasaran pelatihan kewirausahaan secara spesifik termasuk dalam kategori masyarakat transisi. Dalam konteks ini adalah masyarakat pedesaan yang mengalami transisi ke arah kebiasaan kota, yaitu pergeseran tenaga kerja dari pertanian, dan mulai masuk ke sektor industri.

Keberhasilan lulusan pelatihan terhadap pencapaian tujuan pembelajaran berupa dampak yang dapat dilihat pasca kegiatan pelatihan berlangsung, akan mendapatkan pengaruh yang signifikan dari berbagai aspek baik dalam diri maupun lingkungan sekitar. Pengaruh dimaksud disebut dampak (outcome) pelatihan dari penyelenggaraan pelatihan pendidikan kewirausahaan masyarakat (PKM) di PKBM Jelita Masa Kecamatan Majalaya Kabupaten Bandung. Dampak pelatihan yang terjadi berupa perilaku berwirausaha pada peserta pascapelatihan, tentunya tidak terlepas dari hubungan antara komponenkomponen pelatihan yang saling berkaitan. $\mathrm{Hal}$ ini seperti yang diungkapkan oleh Sudjana (2007: 5) bahwa komponen pelatihan terdiri dari: masukan mentah (raw input), masukan sarana (instrumental input), masukan lingkungan (environmental input), proses, keluaran (output), masukan lain (other input), dan pengaruh (outcome).

Berdasarkan pemikiran tersebut, beberapa hal yang menjadi fokus dalam tulisan ini adalah mencakup keluaran (output) berupa hasil pelatihan, efikasi diri sebagai bentuk keyakinan diri dengan kemampuannya untuk mulai melakukan usaha pasca pelatihan, dan dampak (outcome) berupa perilaku berwirausaha peserta pasca pelatihan pada pendidikan kewirausahaan masyarakat di PKBM Jelita Masa Kecamatan Majalaya Kabupaten Bandung, yang divisualisasikan dalam kerangka berpikir sebagaimana pada Gambar 1.

Alur pemikiran tersebut menjadi latar belakang bagi penulis untuk melakukan panelitian berkenaan dengan penyelenggaraan pelatihan pendidikan kewirausahaan masyarakat (PKM) di PKBM Jelita Masa Kecamatan Majalaya, Kabupaten Bandung, yang dianggap berhasil mencetak lulusan pelatihan yang mampu berdaya saing, dan terampil dalam mencari dan memanfaatkan peluang usaha di lingkungan yang kompetitif.

Kajian teori yang dibahas berkaitan

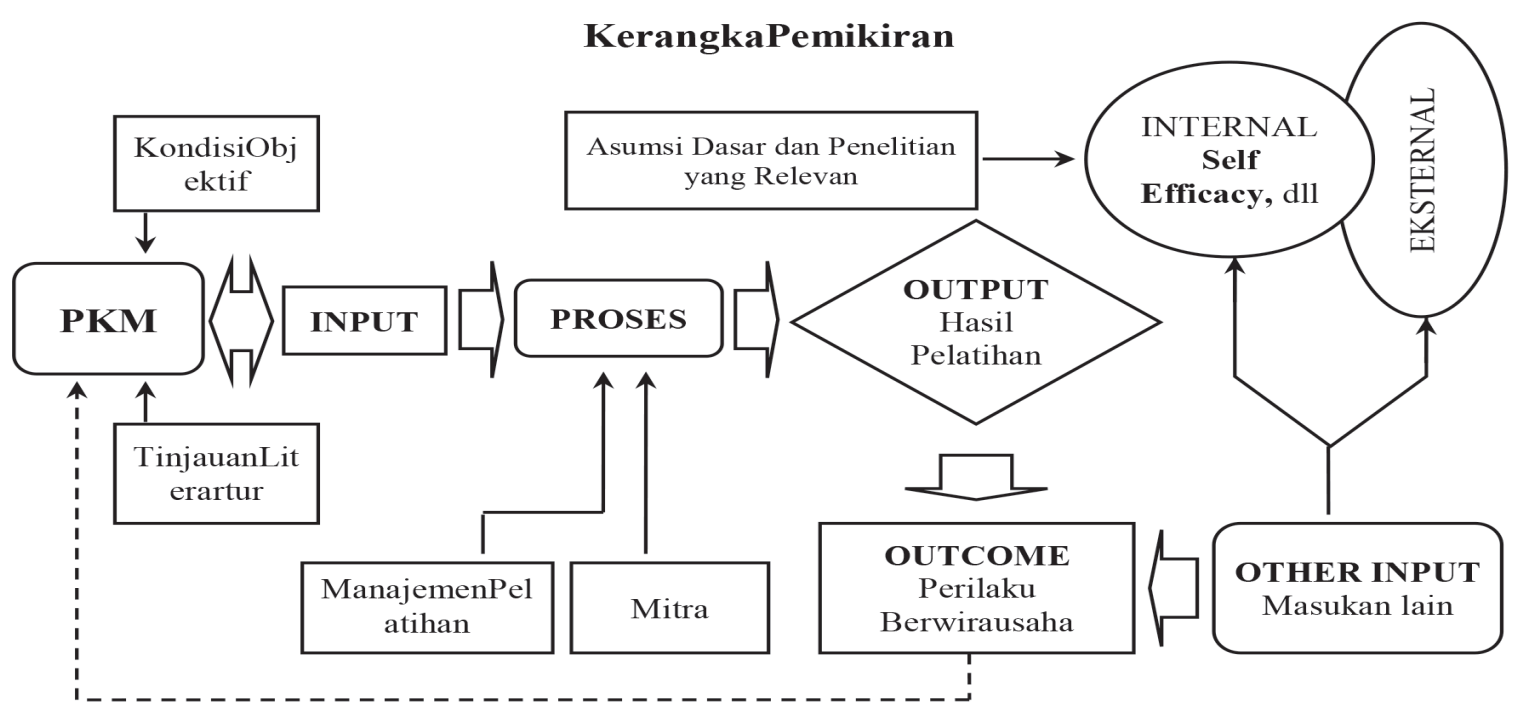

Gambar 1 Kerangka Pemikiran 
dengan variabel penelitian diantaranya meliputi; (1) konsep pendidikan luar sekolah, (2) konsep pelatihan; (3) konsep efikasi diri; dan (4) teori kewirausahaan.Konsep pendidikan luar sekolah sebagai salah satu subsistem pendidikan nasional memiliki ruang lingkup yang sangat luas dan kompleks. Secara teoretis Sudjana, (2000 hlm. 34) mendefinisikan pendidikan luar sekolah sebagai:

\begin{abstract}
"setiap kegiatan terorganisasi dan sistematis, diluar sistem persekolahan yang mapan, dilakukan secara mandiri atau merupakan bagian penting dari kegiatan yang lebih luas, yang sengaja dilakukan untuk melayani peserta didik tertentu di dalam mencapai tujuan belajarnya".
\end{abstract}

Konsep Pelatihan sebagai bagian dari pendidikan profesi didefinisikn oleh Sikula (Sutrisno, $2009 \mathrm{hlm}$. 72) yang mendeskripsikan bahwa pelatihan merupakan proses pendidikan jangka pendek yang menggunakan prosedur sistematis dan terorganisasi, yang mana tenaga kerja non manajerial mempelajari pengetahuan dan keterampilan teknis untuk tujuan-tujuan tertentu.

Konsep efikasi diri merupakan varibel penting dalam penelitian ini dideskripsikan oleh banyak ahli. Bandura (1997: 2) mendefinisikan efikasi diri sebagai kepercayaan seseorang atas kemampuan dirinya untuk menyelesaikan suatu pekerjaan. Atau dengan kata lain, kondisi motivasi seseorang yang lebih didasarkan pada apa yang mereka percaya dari pada apa yang secara objektif benar. Persepsi pribadi seperti ini memegang peranan penting dalam pengembangan intensi seseorang. Efikasi diri yaitu kepercayaan (persepsi) individu mengenai kemampuan untuk membentuk suatu perilaku berwirausaha.Keyakinan kepada kemampuan sendiri memengaruhi motivasi pribadi, makin tinggi efikasi diri maka tingkat stres makin rendah. Sebaliknya, makin tinggi keyakinan kepada kemampuan sendiri, maka makin kokoh tekadnya untuk menyelesaikan tugas dengan baik.

Keyakinan kepada efikasi memengaruhi tingkat tantangan dalam menyelesaikan tugas. Secara singkat dapat dikatakan bahwa bukan hanya kemampuan kerja yang menentukan keberhasilan pelaksanaan tugas, melainkan juga ditentukan oleh tingkat keyakinan pada kemampuan sehingga dapat menambah intensitas motivasi dan kegigihan kerja seseorang. Definisi tersebut dikaitkan dengan pengambilan keputusan atas kemampuan yang dimiliki seseorang dalam menghadapi situasi di masa mendatang. Hal ini didukung oleh pandangan Bandura dalam (Luthans, 2005: 2) yang menyatakan bahwa efikasi diri merupakan penilaian atau keyakinan tentang "seberapa baik seseorang dapat melakukan tindakan yang diperlukan untuk berhubungan dengan situasi prospektif." Definisi yang lebih luas dan lebih tepat untuk perilaku organisasi positif diberikan Stajkovic dan Luthans dalam (Luthans, 2005: 27):

bahwa efikasi diri mengacu pada keyakinan individu mengenai kemampuannya untuk memobilisasi motivasi, sumber daya kognitif, dan tindakan yang diperlukan agar berhasil melaksanakan tugas dalam konteks tertentu. Individu yang mempunyai ekspektasi efikasi diri yang rendah akan berpengaruh terhadap perilakunya yang rendah pula.

Bandura dalam Luthans (2005: 23) merumuskan bahwa ekspektasi menentukan perilaku atau kinerja dilakukan atau tidak, oleh karena itu ekspektasi sangat menentukan kontribusi pada perilaku bahkan juga menjadi penentu lama tidaknya suatu perilaku dapat dipertahankan bila dihadapkan dengan masalah.

Konsep kewirausahaan, dimaknai sebagai suatu proses menciptakan sesuatu dengan menggunakan waktu dan kegiatan disertai modal, jasa dan risiko serta menerima balas jasa, kepuasan, dan kebebasan pribadi. Kewirausahaan berasal dari enterpreneurship yang berarti perilaku dinamis, berani mengambil risiko, reaktif, dan berkembang. Suryana (2003) mengungkapkan bahwa:

"kewirausahaan adalah kemampuan kreatif
dan inovatif yang dijadikan dasar, kiat dan
sumberdaya untuk mencari peluang menuju
sukses." Keputusan berwirausaha merupakan
perilaku dengan keterlibatan tinggi (high
involvement) karena dalam mengambil
keputusan akan melibatkan faktor internal
seperti kepribadian, persepsi, motivasi,
pembelajaran (sikap), faktor eksternal seperti
keluarga, teman, tetangga dan lain sebagainya
(norma subjektif). Kemudian mengukur kontrol
keperilakuan yang dirasakan (efikasi diri), yaitu
suatu kondisi bahwa orang percaya tindakan
itu mudah atau sulit untuk dilakukan dengan
memahami berbagai risiko atau rintangan-
rintangan yang ada apabila mengambil
tindakan tersebut (Ajzen, 2008: 12).

Pendekatan yang digunakan dalam penelitian ini yaitu kuantitatif dengan metode deskriptif analitik. Sebagaimana diungkapkan Travers dalam Sugiyono (2012: 24)

"penelitian deskriptif bertujuan untuk menggambarkan sifat sesuatu yang tengah berlangsung pada saat penelitian dilakukan dan memeriksa sebab-sebab dari suatu gejala 
tertentu".

Hubungan keterkaitan ini dapat digambarkan secara sederhana melalui kerangka pemikirantersebut pada Gambar 2 berikut:

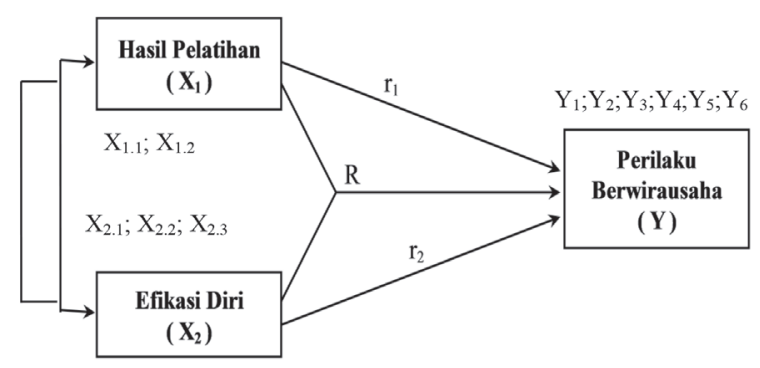

Gambar 2

Hubungan Antara Variabel Penelitian

Rancangan pemikiran penelitian yang tergambar dalam hubungan keterkaitn antara variabel di atas, merupakan model hubungan ganda dengan dua variabel independen $X_{1}$ ,yaitu hasil pelatihan peserta pasca kegiatan yang diperoleh dari hasil evaluasi nara sumber dan penyelenggara dengan indikator pengetahuan, keterampilan, sikap dan nilai; $X_{2}$ yaitu efikasi diri berupa keyakinan, kepercayaan (persepsi) peserta pasca pelatihan mengenai kemampuannya untuk melakukan dan menyelesaikan tugas atau pekerjaan, dalam hal ini membentuk suatu perilaku berwirausaha dengan indikator taraf keyakinan dan kemampuan dalam menentukan tingkat kesulitan tugas atau masalah yang dihadapi dalam berwirausaha, taraf keyakinan peserta terhadap kemampuannya dalam mengatasi masalah dalam melaksanakan usaha, taraf keyakinan dan kemampuan peserta dalam mengeneralisasikan tugas dan pengalaman sebelumnya, baik pengalaman hidup maupaun pengalaman ketika mengikuti pelatihan yang diselenggarakan oleh PKBM Jelita Masa; dan variabel dependen Y, yaitu perilaku berwirausaha peserta pascapelatihan dengan indikator percaya diri, berorientasi pada tugas dan hasil, pengambil risiko, kepemimpinan, keorsinilan, dan berorientasi ke masa depan.

Subjek penelitian adalah seluruh Iulusan peserta pendidikan kewirausahaan masyarakat yang diselenggarakan oleh PKBM Jelita Masa, Kecamatan Majalaya, Kabupaten Bandung, yang berjumlah 60 orang, yang terbagi ke dalam tiga kelompok jenis keterampilan program kewirausahaan masyarakat (PKM) yakni menjahit, pertukangan, dan baki hantaran. Penarikan sampel penelitian dilakukan oleh peneliti dengan mempergunakan probability sampling dengan tujuan untuk memberikan peluang yang sama pada setiap anggota populasi untuk dipilih menjadi sampel.Adapun teknik yang digunakan adalah area sampling (cluster sampling) dengan jumlah sampel sebanyak 30 orang

Teknik pengumpulan data yang digunakan dalam penelitian ini adalah pengumpulan data melalui kuesioner sebagai kegiatan utama, studi dokumentasi dan studi literatur sebagai pendukung pengumpulan data. Instrumen yang digunakan adalah angket dan lembar obsrevasi. Selanjutnya, teknik analisis data menggunakan analisis regresi, untuk menguji besarnya pengaruh hasil pelatihan dan efikasi diri terhadap perilaku berwirausaha peserta pasca pelatihan dan dengan analisis korelasional untuk menguji besarnya hubungan hasil pelatihan dan efikasi diri dengan perilaku berwirausaha peserta pasca pelatihan di PKBM Jelita Masa, Kec. Majalaya, Kab. Bandung.

Tujuan penelitian ini adalah untuk menguji kebenaran suatu hipotesis yang dilaksanakan melalui pengumpulan data di lapangan, mengenai pengaruh hasil penelitian dan efikasi diri terhadap perilaku berwirausaha peserta pascapelatihan sebagai dampak pelatihan pada pendidikan kewirausahaan masyarakat.

\section{Kontribusi Hasil Pelatihan terhadap Perilaku Berwirausaha Peserta Pasca Pelatihan}

Berdasarkan data hasil penelitian diperoleh informasi bahwa hasil pelatihan mempunyai hubungan fungsional dengan perilaku berwirausaha peserta pasca pelatihan pada program PKM di PKBM Jelita Masa, Kecamatan Majalaya, Kabupaten Bandung. Hasil pelatihan terhadap perilaku berwirausaha peserta dinyatakan dengan persamaan regresi linier sederhana dan besarnya hubungan variabel $X_{1}$ dengan $Y$ adalah sebesar $r=0,504$, artinya kontribusi variabel $X_{1}$ terhadap $Y$ sebesar 25,39\%.

Besarnya tingkat perubahan pada ratarata perilaku berwirausaha $(Y)$ diperkirakan sebesar 1,806, untuk setiap penambahan hasil belajar (X1) sebesar satu satuan, atau setiap nilai hasil pelatihan peserta bertambah 10, maka nilai rata-rata perilaku bewirausaha secara positif akan bertambah sebesar 18,06. Hasil pelatihan peserta mempunyai pengaruh yang signfikan dan positif terhadap perilaku berwirausaha. Artinya, semakin tinggi hasil 
pelatihan peserta, maka semakin tinggi pula intensitas perilaku berwirausaha peserta pasca pelatihan.

Analisis lebih lanjut menunjukan bahwa variabel hasil pelatihan juga memberikan kontribusi sebesar 25,39\% terhadap variabel perilaku berwirausaha. Hal ini mengandung makna bahwa ketergantungan variabel perilaku berwirausaha terhadap hasil pelatihan cukup signifikan yaitu sebesar $25,39 \%$ sedangkan sisanya yaitu $74,61 \%$ dipengaruhi oleh faktorfaktor lain. Dengan demikian apabila ingin memperbesar atau meningkatkan intensitas perilaku berwirausaha peserta pasca pelatihan bisa dilakukan dengan jalan meningkatkan hasil pelatihan yang telah dicapai oleh peserta pelatihan.

Lebih lanjut lagi hasil pelatihan memberikan pengaruh yang signifikan dan positif, terutama pada aspek variabel perilaku berwirausaha yaitu aspek percaya diri dengan besar ketergantungan 25,50\% dan aspek berorientasi pada tugas dan hasil dengan besar ketergantungan 26,11\%. Adapun aspek dari hasil pelatihan yang lebih dominan memberikan pengaruh yang signifikan terhadap perilaku berwirausaha peserta adalah aspek hasil psikomotor peserta pelatihan dengan besar nilai koefisien determinasi sebesar 25\%.

Sejalan dengan hasil penelitian ini, dalam beberapa literatur banyak dikemukakan tentang adanya keterkaitan antara hasil pelatihan (output) dengan perilaku berwirausaha (dampak). Dalam tataran teoretis Sudjana (2007:5) mengungkapkan mengenai adanya hubungan fungsional antara hasil pelatihan dengan komponen pendidikan dan pelatihan yang terdiri atas: masukan mentah (raw input), masukan sarana (instrumental input), masukan lingkungan (environmental input), proses, keluaran (output), masukan lain (other input), dan pengaruh (outcome).

Dalam sebuah hasil penelitian tentang pelaksanaan pelatihan program Pendidikan Kewirausahaan Masyarakat (PKM) disimpulkan bahwa pendidikan kewirausahaan yang selama ini telah dilaksanakan di berbagai wilayah merupakan salah satu faktor penting untuk menumbuhkan dan mengembangkan hasrat, jiwa dan perilaku berwirausaha di kalangan generasi muda (Kourilsky dan Walstad, 1998: 21). Sejalan dengan paparan diatas, Purwadi (2010: 120)mengemukakan bahwa dampak pelatihan terhadap peningkatan kemampuan berusaha adalah positif. Dengan kata lain, dampak pelatihan yang dilaksanakan memberikan kontribusi positif dan signifikan terhadap kemampuan berusaha peserta pelatihan.

Hasil penelitian yang dilakukan peneliti mengenai terdapatnya hubungan dan pengaruh yang signifikan antara hasil pelatihan terhadap perilaku berwirausaha, juga memberikan penguatan terhadap pendapat yang mengungkapkan bahwa pengembangan diri untuk mendapatkan keterampilan sebagai modal untuk mengerjakan sesuatu (tugas/ pekerjaan) secara efektif dapat kita peroleh melalui pelatihan. Ungkapan tersebut yang menyatakan sejalan dengan pendapat Sutaryat (2011: 4) "bahwa pengembangan diri merupakan area yang paling cepat berkembang dalam pelatihan."

Ahli lainnya seperti Edwin B. Flippo dalam (Moekijat, 1993: 24), mengungkapkan pelatihan merupakan suatu tindakan untuk meningkatkan pengetahuan dan keterampilan agar karyawan dapat mengerjakan suatu pekerjaan tertentu. Lebih lanjut dalam tataran teoretis, Sudjana (2007: 5) memberikan isyarat bahwa setiap kegiatan edukatif dalam pelatihan dapat membawa keadaan perilaku peserta pelatihan kepada kondisi yang lebih baik, sebagaimana diinginkan oleh organisasi.

\section{Kontribusi Efikasi Diri terhadap Perilaku Berwirausaha Peserta Pasca Pelatihan}

Berdasarkan data hasil penelitian diperoleh informasi bahwa efikasi diri mempunyai hubungan fungsional dengan perilaku berwirausaha peserta pasca pelatihan pada program PKM di PKBM Jelita Masa, Kecamatan Majalaya, Kabupaten Bandung. Pengaruh efikasi diri terhadap perilaku berwirausaha peserta dinyatakan dengan persamaan regresi linier sederhana dan besarnya hubungan variabel $X_{2}$ dengan $Y$ adalah sebesar $r=0,805$. Artinya, kontribusi variabel $X_{2}$ terhadap $Y$ sebesar $64,84 \%$. Besarnya tingkat perubahan para rata-rata perilaku berwirausaha $(\mathrm{Y})$ diperkirakan sebesar 0,987 satuan, untuk setiap penambahan efikasi diri $\left(\mathrm{X}_{2}\right)$ sebesar satu satuan.Hal ini berarti bahwa semakin tinggi efikasi diri peserta maka semakin tinggi pula perilaku berwirausaha peserta pasca pelatihan.

Selanjutnya, hasil analisis koefisien korelasi juga menunjukkan bahwa besarnya harga koefisien adalah 0,805 dengan koefisien determinasi $64,84 \%$. Berdasarkan hasil nilai koefisien determinasi ini diketahui bahwa 
variabel efikasi diri memberikan kontribusi terhadap variabel perilaku berwirausaha peserta pasca pelatihan sebesar $64,84 \%$; sedangkan sisanya, sebesar $35,16 \%$ dipengaruhi oleh faktor-faktor lain. Kemudian, setelah diadakan pengujian terhadap keberartian hubungan (koefisien korelasi) yang terjadi antara efikasi diri dengan perilaku berwirausaha diperoleh harga yang signifikan. Artinya, hubungan tersebut bermakna. Dengan demikian maka hipotesis kedua yang diajukan dalam penelitian ini, yaitu terdapat pengaruh yang signifikan antara efikasi diri terhadap perilaku berwirausaha peserta pasca pelatihan, dapat diterima.

Temuan tentang pola persamaan regresi yang positif dan koefisien korelasi yang signifikan antara variabel efikasi diri $\left(X_{2}\right)$ dengan variabel perilaku berwirausaha $(Y)$ tersebut memberikan arti bahwa efikasi diri secara singkat dapat dikatakan bukan hanya kemampuan kerja yang menentukan keberhasilan pelaksanaan tugas/pekerjaan, melainkan juga ditentukan oleh tingkat keyakinan pada kemampuan sehingga dapat menambah intensitas motivasi dan kegigihan kerja seseorang.

Selaras dengan pendapat yang dikemukakan oleh Bandura dalam Luthans (2005:34) yang merumuskan bahwa ekspektasi menentukan perilaku atau kinerja dilakukan atau tidak, oleh karena itu ekspektasi sangat menentukan kontribusi pada perilaku bahkan juga menjadi penentu lama tidaknya suatu perilaku dapat dipertahankan bila dihadapkan dengan masalah.

Individu yang mempunyai ekspektasi efikasi diri yang tinggi akan berpengaruh terhadap perilakunya yang tinggi pula. Begitupun sebaliknya, sehingga secara linier efikasi yang tinggi dari seseorang juga akan sangat memberikan pengaruh terhadap perilaku yang tinggi (positif) untuk mengerjakan tugas/pekerjaan. Dalam penelitian yang peneliti lakukan tergambar dengan nilai koefisien determinasi efikasi diri peserta sebesar $54,30 \%$ yang turut berkontribusi terhadap perilaku berwirausaha peserta pasca pelatihan, dengan sisanya dari pengaruh faktor lain.

Hasil penelitian ini juga mendukung terhadap beberapa penelitian yang telah dilakukan mengenai variabel-variabel yang memengaruhi intensi dan perilaku berwirausaha. Wijaya (2008: 11) menemukan bahwa, "sikap, norma subjektif dan efikasi diri secara simultan berpengaruh terhadap intensi dan perilaku berwirausaha." Azjen dan Fishbein (1988: 49) dalam theory of planned behavior membuktikan bahwa "intensi dan perilaku berwirausaha tidak hanya dipengaruhi oleh sikap, norma subjektif akan tetapi kontrol perilaku (efikasi diri) juga turut memengaruhi perilaku berwirausaha."

Secara konseptual, efikasi diri yang dimaksud merujuk pada orang yang memunyai kapasitas yang digunakan untuk mendapatkan hasil atau pengaruh yang diinginkannya. Adapun secara khususnya efikasi diri merupakan keyakinan seseorang bahwa dia dapat menjalankan suatu tugas pada suatu tingkat tertentu, yang memengaruhi tingkat pencapaian tugasnya (Bandura, 1986: 61). Dalam bahasa lain, efikasi diri dapat diartikan berupa keyakinan peserta pascapelatihan mengenai kemampuannya untuk memobilisasi motivasi, sumber daya kognitif, dan tindakan yang diperlukan agar berhasil dalam berwirausaha pasca pelatihan program PKM di PKBM Jelita, Masa, Kecamatan Majalaya, Kabupaten Bandung,yang cukup beragam dari setiap individunya. Hal ini berdasarkan evaluasi hasil pendampingan terhadap peserta pascapelatihan, yang merekomendasikan pelaksanaan pendampingan dan pembinaan hendaknya dilakukan secara kontinu untuk terus memupuk kepercayaan dan keyakinan peserta akan kemampuannya untuk merintis usaha mandiri.

Efikasi diri dalam penelitian ini merupakan gambaran efikasi diri peserta pascapelatihan yang diperoleh dari hasil pengukuran indikatornya yang mencakup aspek magnitude/level dengan indikator, berpandangan optimis dalam mengerjakan tugas/karier, mampu menilai minat terhadap pencapain karier, mengembangkan kemampuan dan prestasi, membuat rencana dalam menyelesaikan tugas-tugas perkembangan karier, merasa yakin dapat melakukan dan menyelesaikan pekerjaan, melihat tugas yang sulit sebagai suatu tantangan, belajar sesuai dengan jadwal yang diatur, dan bertindak selektif dalam mencapai tujuannya.

Aspek kekuatan dengan indikator, usaha yang dilakukan dapat meningkatkan prestasi dengan baik, komitmen dalam menyelesaikan tugas-tugas yang diberikan, percaya dan mengetahui keunggulan yang dimiliki, kegigihan dalam menyelesaikan tugas, 
memiliki tujuan yang positif dalam melakukan berbagai hal, memiliki motivasi yang baik terhadap dirinya sendiri untuk pengembangan dirinya, serta aspek generalisasi (generality) dengan indikator, menyikapi situasi yang berbeda dengan baik dan berpikir positif, menjadikan pengalaman kehidupan sebagai jalan mencapai kesuksesan, suka mencari situasi baru, dapat mengatasi segala situasi dengan efektif, dan mencoba tantangan baru.

Dalam beberapa hal, efikasi diri juga berkaian dengan keunggulan pada diri seseorang untuk bersaing (kompetitif), berupa motivasi dalam proses meningkatkan kesejahteraan individu. Dalam studinya, Raden Rudi Alhempi, dkk, (2014: 1) menjelaskan bahwa pertumbuhan ekonomi didorong oleh efek pertumbuhan provinsi, efek campuran industri, dan pengaruh keunggulan kompetitif.

\section{Kontribusi Pengaruh Hasil Pelatihan dan Efikasi Diri terhadap Perilaku Berwirausaha Peserta Pascapelati- han}

Berdasarkan data hasil penelitian diperoleh informasi bahwa hasil pelatihan dan efikasi diri secara bersama-sama memunyai hubungan fungsional dengan perilaku berwirausaha peserta pasca pelatihan pada program PKM di PKBM Jelita Masa, Kecamatan Majalaya, Kabupaten Bandung. Pengaruh hasil pelatihan dan efikasi diri terhadap perilaku berwirausaha peserta dinyatakan dengan persamaan regresi linier ganda, dan besarnya hubungan variabel $X_{1}, X_{2}$, dengan $Y$ adalah sebesar $r=0,806$. Artinya, kontribusi variabel $X_{1}, X_{2}$ terhadap $Y$ sebesar $65,04 \%$.

Hal ini memberikan arti bahwa setiap perubahan peningkatan satu satuan pada variabel hasil pelatihan $\left(X_{1}\right)$ sebesar 0,199 satuan dan efikasi diri $\left(X_{2}\right)$ sebesar 0,947 satuan akan diikuti pula pada peningkatan variabel perilaku berwirausaha $(Y)$ sebesar 9,796 satuan. Berdasarkan hasil analisis lebih lanjut juga ditemukan bahwa antara variabel hasil pelatihan dan efikasi diri peserta secara bersama-sama juga memunyai pengaruh yang signifikan terhadap intensitas perilaku berwirausaha peserta pasca pelatihan. Hal ini mengandung arti bahwa semakin tinggi hasil pelatihan peserta dan semakin tinggi efikasi diri peserta pelatihan, maka semakin tinggi pula hasil pula intensitas perilaku berwirausaha peserta pascapelatihan. Kontribusi kedua variabel tersebut sebesar $65,04 \%$ terhadap variabel perilaku berwirausaha peserta pasca pelatihan, sedangkan sisanya sebesar $34,96 \%$ dipengaruhi oleh faktor-faktor lain.

Hasil pengukuran pelatihan dinilai pada dua aspek yaitu, aspek pengetahuan dan aspek keterampilan. Berdasarkan hasil penelitian yang dilakukan, ternyata diperoleh nilai rata-rata pada aspek keterampilan peserta sebesar 77,33 dan nilai rata-rata aspek pengetahuan peserta pelatihan sebesar 74,33 . Besarnya nilai rata-rata pada aspek keterampilan sesuai dengan tujuan pendidikan nonformal yang lebih cenderung berfokus pada pengembangan perubahan keterampilan dibandingkan pengetahuan (kognitif) peserta. $\mathrm{Hal}$ ini sesuai dengan pendapat dari Sudjana (2004:37) yang mengungkapkan bahwa dalam pendidikan nonformal, perubahan ranah psikomotor atau keterampilan lebih diutamakan disamping perubahan ranah kognitif dan afektif.

Hasil pengukuran intensitas efikasi diri peserta pelatihan tergolong cukup, yaitu dengan nilai rata-rata kecenderungan jawaban peserta sebesar 128,50 dari skor idealnya 190 , atau sekitar $67,63 \%$. Dengan kata lain, memang setiap individu, dalam hal ini peserta pelatihan memunyai keyakinan diri atau efikasi diri yang cukup atau standar dalam melakukan pekerjaan atau berwirausaha untuk dapat meraih keberhasilan. Secara teoretis, efikasi diri (self efficacy) merujuk kepada keyakinan atau kepercayaan seseorang bahwa dia memiliki kemampuan, motivasi, dan sumber daya untuk menyelesaikan suatu tugas dengan berhasil (McShane \& Glinow, 2004: 51). Dalam penelitian ini, peserta dengan kategori efikasi diri yang tinggi cenderung memiliki sikap percaya diri terhadap pekerjaan maupun dalam menjalankan usaha serta siap menghadapi tantangan dalam hidupnya, begitupun sebaliknya. Hal ini sesuai dengan pendapat Sumahamidjaja dalam Suryana (2006: 40) bahwa,

orang yang memiliki kepercayaan diri akan memiliki kemampuan untuk bekerja dalam mengorganisasi, mengawasi dan meraih kesuksesan.

Hasil pengukuran terhadap perilaku berwirausaha peserta pasca pelatihan tergolong pada kategori yang cukup. Hal tersebut dapat dilihat dari nilai rata-rata kecenderungan jawaban peserta sebesar 146,63 dari skor idealnya 220, atau sekitar $66,65 \%$ dari skor idealnya. Dengan kata lain, memang peserta pelatihan memunyai intensitas 
perilaku berwirausaha yang cukup atau standar pascakegiatan pelatihan ditunjukan dengan bentuk kreativitas, sikap, semangat, perilaku, dan kemampuan seseorang untuk mencari peluang atau menjalankan usaha atau kegiatan yang mengarah pada upaya kerja, yang ditunjukkan oleh peserta pasca pelatihan, untuk meningkatkan penghasilan dan atau taraf hidupnya. Hal tersebut juga senada dengan laporan bulanan hasil monitoring yang dilakukan pihak penyelenggara pascapelatihan, yang memberi gambaran kondisi peserta bahwa, peserta yang merintis wirausaha mandiri sesuai dengan keterampilan yang diperoleh hampir sebesar $50 \%$ dari lulusan, indikasi tergolong cukup berdasarkan indikator keberhasilan penyelenggara pelatihan.

Hasil pelatihan yang baik dari peserta dan efikasi diri dari peserta yang tinggi akan membuat perilaku berwirausaha peserta pasca pelatihan akan semakin meningkat. Oleh karena itu, dapat ditarik kesimpulan bahwa kedua variabel tersebut sama-sama berperan atau memunyai pengaruh signifikan terhadap perilaku berwirausaha. Berdasarkan hasil analisis data seperti tersebut di atas, maka hipotesis tiga yang diajukan dalam penelitian ini, yaitu "terdapat pengaruh yang signfifikan antara hasil pelatihan dan efikasi diri dengan perilaku berwirausaha peserta pasca pelatihan," diterima.

Pembahasan terhadap hasil penelitian dengan teori yang relevan menunjukkan adanya keterkaitan dan hubungan signifikan. Eratnya keterkaitan antara hasil pelatihan dan efikasi diri dengan perilaku berwirausaha juga dikemukakan secara tersirat berdasarkan Theory of Planned Behavior (Ajzen, 2008:5)

bahwa sebuah perilaku dengan keterlibatan tinggi membutuhkan keyakinan dan evaluasi untuk menumbuhkan sikap, norma subjektif, dan kontrol keperilakuan dengan intensi sebagai mediator pengaruh berbagai faktorfaktor motivasional yang berdampak pada suatu perilaku.

Keputusan berwirausaha merupakan perilaku dengan keterlibatan tinggi (high involvement), karena dalam mengambil keputusan akan melibatkan faktor internal seperti kepribadian, persepsi, motivasi, pembelajaran (sikap), faktor eksternal seperti keluarga, teman, tetangga dan lain sebagainya (norma subjektif). Kemudian, mengukur kontrol keperilakuan yang dirasakan (efikasi diri) yaitu suatu kondisi bahwa orang percaya tindakan itu mudah atau sulit untuk dilakukan dengan memahami berbagai risiko atau rintangan-rintangan yang ada apabila mengambil tindakan tersebut (Ajzen, 2008: 59).

Dalam konsep pendidikan nonformal, hubungan dan pengaruh yang signifikan antara hasil pelatihan peserta sebagai bentuk dari keluaran (output) sebuah proses pembelajaran dan efikasi diri peserta sebagai bentuk lain dari masukan lain (other input) dalam sebuah komponen pembelajaran pendidikan nonformal dan perilaku berwirausaha sebagai bentuk dari pengaruh (outcome) ini telah terbukti.

Variabel hasil pelatihan dalam konsep pendidikan nonformal sebagai variabel bebas satu yaitu bentuk dari keluaran (output) yang merupakan tujuan antara pendidikan nonformal sebagaimana dikemukakan (Sudjana, 2004: 37) bahwa keluaran mencakup kuantitas lulusan disertai kualitas perubahan perilaku yang didapat dari kegiatan pembelajaran. Lebih lanjut diungkapkan bahwa perubahan perilaku tersebut mencakup ranah kognitif, afektif dan psikomotor yang sesuai dengan kebutuhan belajar yang mereka perlukan sehingga berdasarkan hal tersebut secara eksplisit dapat kita lihat bahwa hasil pelatihan berupa (output) berkaitan atau mempunyai keterkaitan dengan perubahan perilaku individu pasca proses pembelajaran dalam hal ini proses pelatihan program PKM di PKBM Jelita Masa, Kacamatan Majalaya, Kabupaten Bandung.

Variabel efikasi diri, menurut Bandura dalam Luthans (2005: 338), adalah mengacu pada keyakinan individu mengenai kemampuannya untuk memobilisasi motivasi, sumberdaya kognitif, dan tindakan yang diperlukan, agar berhasil melaksanakan tugas dalam konteks tertentu. Individu yang memiliki efikasi tinggi berfokus pada peluang yang layak dikejar dan melihat rintangan sebagai hal yang dapat diatasi. Individu dengan efikasi diri tinggi pasti akan mengharapkan keberhasilan dan mendapatkan yang diinginkan dan insentif hasil yang positif. Seseorang yang memiliki efikasi diri secara tidak langsung melakukan kajian dan penelitian sehingga dapat berhasil melaksanakan tugas. Hal tersebut sejalan dengan pemikiran Jackman yang dikutif Yusuf Hamdan, dkk. (2013: 239) bahwa penelitian yang cermat dan lengkap akan membangun kepercayaan diri seseorang.

Efikasi diri, menurut banyak ahli sama dengan sikap. Rosenberg dan Hovland yang mengembangkan konsepsinya tentang efikasi 
diri sama dengan sikap (perilaku) yang diadopsi dari Azjen dan Fishbein (1988: 28). Ia mengungkapkan bahwa:

\begin{abstract}
Sikap seseorang terhadap suatu objek selalu berperanan sebagai perantara antara responsnya dan objek yang bersangkutan. Respons diklasifikasikan dalam tiga macam, yaitu respons kognitif (respons perseptual dan pernyataan tentang apa yang diyakini), respons afektif (respons pernyataan perasaan), serta respons konasi (pernyataan mengenai perilaku). Masing-masing klasifikasi respons ini berhubungan dengan ketiga komponen sikap. Dengan melihat salah satu di antara ketiga bentuk respons tersebut sikap seseorang sudah dapat diketahui.
\end{abstract}

Respons terhadap stimulus sebagai bentuk dari sikap (perilaku), yang di antara salah satunya mengenai respons kognitif mengenai respons perseptual dan pernyataan yang diyakini, hal ini memberi indikasi bahwa keyakinan terhadap kemampuan untuk melakukan sesuatu pasca pelatihan sebagai bentuk dari respons terhadap stimulus (peluang) berupa perilaku berwirausaha, memunyai hubungan yang signifikan, sesuai dengan hasil penelitian ini yang mengungkap adanya hubungan yang signifikan antara variabel efikasi diri dengan perilaku berwirausaha.

Keterkaitan efikasi diri dan perilaku berwirausaha dalam penelitian ini juga selaras dengan pendapat Hutagalung (2010:8) bahwa banyak faktor yang memengaruhi keberhasilan usaha para pengusaha, baik yang berasal dari internal maupun eksternal.Faktor internal lebih banyak berasal dari pengusaha itu sendiri, di antaranya adalah:latar belakang pendidikan, usia, pengalaman, efikasi diri, motivasi dan masalah internal lainnya. Faktor eksternal dihadapkan kepada permasalahan di luar organisasi, di antaranya: lingkungan, peluang, persaingan, sistem informasi global, dan masalah eksternal lainnya.

Variabel perilaku berwirausaha sebagai variabel terikat dalam penelitian ini, berdasarkan hasil penelitian, diperoleh hubungan yang signifikan dengan hasil pelatihan dan efikasi diri. Hal ini tercermin dalam persamaan regresi dan nilai korelasi yang dihasilkan. Perilaku berwirausaha dalam penelitian ini sebagai bentuk dari pengaruh (out come) yang merupakan bagian integral dari komponen-komponen pendidikan non formal lainnya. Perilaku berwirausaha sebagai sebuah pengaruh, merupakan tujuan akhir dari pendidikan nonformal, yakni terjadinya perubahan kesejahteraan hidup lulusan yang ditandai dengan perolehan pekerjaan atau berwirausaha, perolehan atau peningkatan pendapatan (Sudjana, 2004: 38).

Kegiatan pelatihan program PKM yang diselenggarakan oleh PKBM Jelita Masa, sebagai upaya yang dilakukan pemerintah dan lembaga pendidikan nonformal untuk meningkatkan keswadayaan masyarakat melalui pemberian keterampilan dan pengetahuan tentang kewirausahaan, dengan tujuan di pascakegiatan mereka dapat memeroleh atau meningkatkan pendapatan dengan memeroleh pekerjaan atau berwirausaha secara mandiri dapat dikatakan berhasil.

Pendapat para ahli dan hasil penelitian tersebut di atas menegaskan bahwa hasil pelatihan yang mencakup kognitif, afektif, psikomotor, dan efikasi diri dalam hal ini keyakinan terhadap kemampuan diri untuk melakukan atau merespons suatu stimulus (peluang) dengan perilaku berwirausaha, hasil pelatihan dan efikasi diri dapat mendorong peserta pelatihan untuk meningkatkan perilaku berwirausaha.

\section{Simpulan dan Saran}

Beberapa simpulan di antaranya, Pertama, hasil pelatihan peserta pada program PKM di PKBM Jelita Masa, Kecamatan Majalaya, Kabupaten Bandung, menunjukkan kondisi yang baik dan kondusif. Hal tersebut menunjukkan pengertian bahwa pengaruh yang signifikan dengan kategori yang cukup atau moderat antara hasil pelatihan terhadap perilaku berwirausaha peserta pascapelatihan. Lebih lanjut maka dapat diungkapkan pula bahwa perilaku berwirausaha peserta dipengaruhi oleh hasil pelatihan. Kedua, nilai rata-rata skor variabel efikasi diri peserta pelatihan pada program PKM di PKBM Jelita Masa, Kecamatan Majalaya, Kabupaten Bandung, memiliki kualifikasi yang cukup baik atau berada pada taraf yang cukup. Adapun hal tersebut di atas didukung oleh cukup baiknya kondisi peserta, keyakinan dan kemampuan diri dalam menentukan tingkat kesulitan tugas/ pekerjaan dan atau masalah yang dihadapi (magnitude), keyakinan peserta terhadap kemampuannya dalam mengatasi masalah /kesulitan dalam melaksanakan tugas /pekerjaan (strength), dan keyakinan dan kemampuan peserta pelatihan dalam mengeneralisasikan tugas/pekerjaan dan pengalaman sebelumnya. Adanya pengaruh yang signifikan antara efikasi diri diri terhadap perilaku berwirausaha, kualifikasi nilai korelasi setelah dikonsultasikan nilai hubungan 
ini berada pada kategori yang tinggi atau erat antara efikasi diri terhadap perilaku berwirausaha peserta pasca pelatihan. Lebih lanjut lagi perilaku berwirausaha peserta pascapelatihan dipengaruhi oleh efikasi diri.

Ketiga, nilai rata-rata skor variabel perilaku berwirausaha peserta pasca pelatihan di PKBM Jelita Masa, Kecamatan Majalaya, Kabupaten Bandung, menunjukkan bahwa perilaku berwirausaha peserta pasca pelatihan memiliki kualifikasi yang baik dan berada pada kategori yang cukup. Dengan demikian, perilaku berwirausaha peserta pasca pelatihan menunjukkan kondisi yang baik sehingga perilaku berwirausaha ini sudah dianggap sesuai standar bagi pengaruh yang diharapkan dari penyelenggaraan pelatihan ini.

Ada pengaruh yang positif dan signifikan antara hasil pelatihan dan efikasi diri terhadap perilaku berwirausaha peserta pasca pelatihan. Artinya, selama ini pengaruh hasil pelatihan dan efikasi diri peserta terhadap perilaku berwirausaha mempunyai pengaruh yang cukup tinggi karena nilai korelasinya berada pada derajat signifikansi yang tinggi atau erat. Maka dengan demikian dapat diungkapkan pula bahwa perilaku berwirausaha peserta pasca pelatihan dipengaruhi oleh hasil pelatihan dan efikasi diri peserta.

Saran dalam tulisan ini, Pertama, pihak yang akan menyelenggarakan pelatihan program PKM perlu menyempurnakan prosedur pelatihan, sehingga hasilnya memberikan kontribusi dan dukungan lebih besar terhadap perilaku peserta dalam berwirausaha pasca pelatihan. Hal tersebut bisa dalam bentuk peningkatan proses pembelajaran maupun proses penilaian agar hasil pelatihan lebih efektif dan efisien. Kedua, bagi pihak peneliti selanjutnya untuk meneliti variabel lain yang berpengaruh pada perilaku berwirausaha dan memegang peranan memberikan kontribusi sisanya tersebut.

\section{Daftar Pustaka}

Azjen, (2008) Attitudes and Attitude Change. Psychology Press: WD Cranoeds

Azjen dan Fishbein(1988) Attitudes, Personality, and Behavior, Dorsey Press: Chicago.
Bandura, A.(1986) Social Foundation of Thoughtand Action. Prentice Hall, Englewood Clift, NJ.

Bandura, A (1997) Self-Efficacy; The Exercise of Control, New York: W.H. Freeman and Company.

Hutagalung, dkk. (2010) Kewirausahaan. USU Press, Medan.

Kourilsky, M. L. dan W. B. Walstad, (1998) "Entrepreneurship and female youth: knowledge, attitude, gender differences, and educational practices." Journal of Business Venturing. Vol. 13 (1) pp. 77-88.

Luthans, F. (2005) Perilaku Organisasi edisi 10. Yogyakarta: Andi

McShane, Stephen L \& Mary Ann Von Glinow. (2004). Organizational Behavior. New York: McGraw-Hill.

Moekijat. (1993) Evaluasi Pelatihan dalam rangka Peningkatan Produktivitas (Perusahaan). Bandung: Mandar Maju.

Purwadi (2010:120) "Studi Dampak Pelatihan Keterampilan Kerja terhadap Kemampuan Berusaha." Bandung: Tesis. Tidak dipublikasikan.

Raden Rudi Alhempi, dkk, (2014). "Keterkaitan Sektor-Sektor Ekonomi Potensial di Provinsi Riau." Jurnal Mimbar: Sosial dan Pembangunan. Volume 30 No. 1 tahun 2014.

Sugiyono. (2012) Metode Penelitian Kombinasi (Mixed Methods). Bandung: Alfabeta.

Sudjana. (2004) Pendidikan Nonformal (Wawasan, Sejarah Perkembangan Filsafat, Teori Pendukung, Azas). Bandung: Falah Production.

Sudjana. (2007) Sistem dan Manajemen Pelatihan (Teori dan Aplikasi). Bandung: Falah Production.

Sutaryat. (2011) Mengelola Pelatihan yang Efektif. Bandung: Prodi PLS SPS UPI.

Sutaryat. (2011) Evaluasi Pelatihan yang Efektif. Bandung:Prodi PLS SPS UPI.

Suryana., (2006) Kewirausahaan Pedoman Praktis, Kiat dan Proses menuju Sukses. Jakarta: Salemba Empat.

Yusuf Hamdan, dkk. (2013). "Profil Negosiator Bisnis Wanita Pengusaha" Jurnal Mimbar: Sosial dan Pembangunan. Volume 29 No. 2 tahun 2013.

Wijaya, T.(2008) "Kajian Model Empiris Berwirausaha UKM DIY dan Jawa Tengah." Jurnal Manajemen dan Kewirausahaan. 